\title{
The Productivity of Power: Hannah ARendt's Renewal of the Classical CONCEPT OF POLITICS
}

\author{
HAUKE BRUNKHORST \\ UNIVERSIDAd de FLeNSBURG, ALEMANIA
}

\begin{abstract}
Resumen
Este artículo resume la concepción de poder desarrollada por Hannah Arendt. Ésta se basa en la convicción de Arendt de que el nacimiento de los gobiernos totalitarios hace que la idea moderna del Estado-nación y de los derechos humanos y ciudadanos vinculados a él entren en una crisis irreversible. Para responder a esta crisis, Arendt concibe el poder como algo independiente de, y en tensión con, cualquier forma de gobierno. El poder estaría caracterizado por la igualdad, dinamismo, lo poco predecible y la capacidad de renovación. El siguiente trabajo intenta mostrar cómo Arendt asoció estas características a los regímenes totalitarios, asignándoles un valor negativo que sólo es reevaluado una vez que realiza su investigación sobre totalitarismos y que proporciona argumentos para afirmar por qué su nuevo concepto de poder es la única respuesta posible a los fenómenos totalitarios.
\end{abstract}

\section{Abstract}

This essay traces the development of Arendt's conception of power. This development corresponds to Arendt's conviction that the advent of totalitarian forms of government set the idea of the modern nationstate, and of the rights of "man and citizen" associated with it, in an irrevocable crisis. To respond to this crisis, Arendt attempts to conceive of power as something separate from, and in tension with, any form of government. Power becomes characterized by its egalitarianism, dynamism, unpredictability, and capacity to innovate. The essay tries to show how these formal characteristics were originally ascribed a purely negative value by Arendt, who associated them with totalitarian power, and that only after her work on totalitarianism does she revaluate them and provides arguments as to why her new concept of power is the only possible response to totalitarian phenomena.

\section{PALABRAS CLAVE • Arendt • Poder • Estado-nación • Totalitarismos}

The concept of power is central to Arendt's thought. Starting with her early habilitation, in which she presents the impenetrable social life of the bourgeois salon as a new historical power, Arendt understands power in terms of potential, as a capacity that is neither outside of the subjects nor at the disposal of a subject. Even art is considered by Arendt not as representation but as the expression of such a power potential. And in her last work, The Life of the Mind, it is once again a concept of power that allows her to reinterpret the Platonic contemplative life (bios theoretikos) as a function of the connection between the solitude of thinking and an inner power of judgment.

But for Arendt, the paradigm of all power remains political power. Political power is opposed to political domination. Power cannot be mastered, instrumentalized or organized through administration, law, or governmental power. Wherever it spontaneously emerges, power challenges those who rule, 
whether they rule in the form of a democratic rule of law or in the form of a tyrannical despotism. Power threatens those who rule with destruction yet, at any moment, it can freeze back into a form of domination, bureaucracy, and despotism. But whereas in The Origins of Totalitarianism these features of power are associated with the highly dynamical movement of negativity, of destruction and self-destruction, a movement which is the characteristic of totalitarian power, in The Human Condition, Arendt assigns to this mobile and unruly power a productive and foundational force which, from then onwards, will contain the heart of her political thought. In this later sense, power is conceived as an essentially inter-subjective capacity that not only destroys and annuls all order, state and law, but simultaneously produces, founds, and establishes them.

Arendt is renowned for her passionate critique of the European nation-state. However, she gained this reputation from the works that follow The Human Condition, primarily On Revolution. Less well-known is that she began her investigation of the origins of totalitarianism as a decisive defender of the nation-state, which at the time she understood to be a Republic, in the sense that the French Revolution gave to this term. Arendt's volte-face towards the nation-state occurs in the middle of her book on totalitarianism, first published in 1951. Arendt begins by assuming that (1) the democratic nation-state such as it was brought forth by the French Revolution allows for political freedom and protects it against the crass impositions of a highly dynamic bourgeois-capitalistic society. Before she takes leave for good of the concept of the nation-state during the 1950s, she defends for a moment (2) the standpoint of liberal rule of law according to which a government of laws is, above all, designed to protect citizens from the claims made on behalf of the idea of nation, understood in nationalistic terms. However, she quickly realizes that the idea of a pure rule of law regime (Rechtsstaat), in which democracy is strictly delimited and can function without democracy in cases of necessity, is historically discredited. Constitutional government alone is much too weak to prevail against the violent expansionism of capitalism, imperialism, and totalitarianism. In order to address this dilemma, Arendt, now living in the United States, rejects the idea of the nation-state, aided by her study of The Federalist Papers and the writings of Thomas Jefferson and James Madison. She then connects (3) this American political theory and the everyday experience of democracy in America which, in effect, saved her life, to a renewed analysis of the concept of power.

(1) In The Origins of Totalitarianism (Arendt, 1979), the Dreyfus Affair is exemplary of public affairs. Public life takes place on the stage provided by the republican-Jacobin nation-state: in the Parliament, the courts, the press, and public assemblies. According to this model of the nationstate, written communication between absent persons mediates all processes of communication, and the nation is coeval with the declaration of the Rights of Man and Citizen. Consequently, Arendt sees in "that Jacobin patriotism for which human rights were always part of its glory" the bond that unifies the nation (Arendt, 1991: 170, trans. Lemm). This patriotism is rooted in the "Latinism" by which the "men of the French Revolution identified mentally with Rome" and needs to be strictly kept apart from all kinds of ethnic, populist or racist forms of nationalism (Arendt, 1979: 164; Arendt, 1991: 276; see also Arendt, 1991: 370-372; Arendt, 1979: 230-1).

In the Latinism of the Jacobins, Arendt recognizes for the first time the origin of a power that can resist the totalitarian powers of society: she writes in 1948, "until now the greatest bulwark against the unlimited domination of bourgeois society, against the conquest of power through the mob and the introduction of imperialistic politics in the structure of Western states has been the nation- 
state. The sovereignty of the nation-state, which once was supposed to express the sovereignty of the people, is now threatened from all sides" (Arendt, 1976: 29, trans. Lemm). The ideas of 1789 -as Arendt puts it in the American edition of Origins- were to triumph for the last time in the First World-War, under Clemenceau's government: “The first World War could still be won by the Jacobin appeal of Clemenceau, France's last son of the Revolution” (Arendt, 1979: 79).

The sovereignty of the people, the rule of law, and individual rights form a well-ordered unity in the republican idea of the nation-state. The nation-state as conceived in the $18^{\text {th }}$ century and realized in the $19^{\text {th }}$ century draws its anti-totalitarian force from this unity. In the republic's hour of destiny, Clemenceau, Zola, Picquart, Labori and other Dreyfusards -as Arendt repeatedly emphasizes- drew their strength from two and only two principles: 1. the "Jacobin principle of the nation based on human rights", and 2. "the republican view of communal life which asserts (in the words of Clemenceau) that by infringing on the rights of one you infringe on the rights of all” (OT, 1979: 106; Arendt, 1991: 187).

Modern republicanism distinguishes itself from its ancient predecessors by founding the Roman principle "potestas in populo" on the Jacobin idea of human rights. Ancient republics did not legitimize particular civic solidarity by appealing to universal rights of freedom. For the universalistic claims of classical humanism, it sufficed that the universal form of the political community be realized in a few splendid exemplars at the top of the social hierarchy of merit and in a single city. The orientation towards the best political regime depended on an environment characterized by corrupt political forms. It excluded from the start the radical egalitarianism that essentially defines modern human rights.

It is only once the modern nation-state begins to combine the ancient principle of the republic with the new idea of human rights that the socially exclusionary, classical paradigm of civic solidarity comes under normative pressure. The strict boundaries which separated the included from the excluded, the citizen from the human being, the property-owners from the property-less, the virtuous from the base, the communicated from the excommunicated, start to lose their contours. The new Jacobin paradigm of civic solidarity -more abstract, egalitarian, and inclusive- opens up the political system for the recognition of the basic rights of those who, like Major Dreyfus, were excluded from all civic rights to honor and fell outside the bounds of "good society," for those who, in Foucault's sense as well as in the sense captured by Arendt's book Rahel Varnhagen, were "infamous men" (Arendt, 1981a: 20, 59, 108, 189). Only within the confines of the republican nation-state could those majorities or minorities threatened by social exclusion -workers and women, as much as Jews or Blacks- have their rights recognized. For Jews, as Arendt soberly notices: "the breakdown of the European system of nation-states was in all respects the greatest of catastrophes" (Arendt, 1976: 46, trans. Lemm).

"Society" and its human substratum, the "masses" and the "mob", are the counter-concepts to this republican idea of public life centered on the "State", the "nation" and "the people": "While the people in all great revolutions fight for true representation, the mob always will shout for the 'strong man', the 'great leader'. For the mob hates society from which it is excluded, as well as Parliament where it is not represented" (Arendt, 1979: 107; Arendt, 1991: 188). This sounds almost like Carl Schmitt, but it isn't. In Arendt's early schema, the republic, the sphere of public affairs, corresponds to her idea of a parliamentary democracy and runs counter to the plebisci- 
tary dictatorship as exemplified in the $18^{\text {th }}$ Brumaire of Louis Bonaparte, under which public life degenerates. However, plebiscitary dictatorship is neither democratic nor liberal in contrast to democratic parliamentarianism and liberalism, which do not constitute an irreconcilable opposition, but rather complement each other.

In any case, for Arendt, it is not the mobilized and manipulable human masses, and even less the phenomenon of plebiscitary dictatorship, that stand at the origin of totalitarianism. Rather, she identifies this origin with a highly abstract, reflexive mechanism: "expansion for the sake of expansion" is what drives the new, bourgeois-capitalistic society toward the imperialistic, boundless self-production and self-enlargement of capital and power. From an imperialistic perspective, power has uncoupled itself from national self-interest, has de-nationalized itself, and is driven to global expansion because imperialistic power produces itself, analogously to a differentiated money economy in the process of its progressive functional differentiation. This idea of society is essentially the counter-concept of the idea of public life.

A rapidly expanding modern society eliminates the state as it appears in the republican nation-state ideal, with the state as separate and superior to society, and instead transforms it into a social organization. The classical political community, in which citizens standout in public self-representation and in which they perfect their political human essence, has become an economics- and success-oriented subsystem. Power, like money, becomes the countable and functional capital of a politics that only retains its name in common with the ancient Polis. Imperialism, Fascism, Nazism and Stalinism are nothing but the self-radicalizations of a social process of power accumulation that annihilates the state as the public affair of all citizens.

The theory according to which the state ceases to be the object of politics and simultaneously gets swallowed up by society was first advanced in the studies on National Socialism by Ernst Fraenkel in the late 1930s (Fraenkel, 1999 and 2001) and by Franz Neumann in the early 1940s (Neumann, 1993). The Nazi-regime, represented by the Hobbesian figure of the Behemoth, is conceived by them as the anti-state. But Arendt, who had at first only applied it to her analysis of German fascism, progressively generalizes the thesis of a reflexively self-increasing and de-centered political power. The first step is to expand this theory to account for Stalinism. In a second step, which she takes in The Human Condition, this thesis is applied in an almost systems-theoretical way to modern society in its entirety. In her account, "capital accumulation" and "power accumulation" are both social and anti-political processes that drive each other forward and strengthen each other. Finally, they overflow all the dams and sluices of the nation-state, tearing down the well-ordered hierarchies of government and law, destroying the sovereign state by turning it into the totalitarian state, first from the inside and then from the outside: "a society which had entered the path of never-ending acquisition had to engineer a dynamic political organization capable of a corresponding never-ending process of power generation" (Arendt, 1979: 146; Arendt, 1991: 248).

Clearly, at this stage, Arendt sees the expansionist dynamic of modern civil society as being exclusively negative, as an unbounded force of destruction. In her book on totalitarianism she recognizes only one, purely negative concept of reflexive power: "power appears as an immaterial mechanism which with its every movement produces more power" (Arendt, 1991: 646, trans. Lemm). Power produces itself and ends up destroying itself in the "bad infinity" (Hegel) of an endless and pointless motion: completely analogously to the motion of capital in Marx's analysis. Power that increases itself reflexively is unlimited power and as such is already totalitarian. The republican nation-state 
is incapable in the long run of resisting this uprising of power because the legally delimited public power at its disposal is oriented toward ends and interests. It is limited and finite and, therefore, cannot be increased in the way that the imperialistic-reflexive power can be. In the long run, the power of the state cannot withstand the continuously growing power of social imperialism.

(2) This is the original thesis that underpins the first seven chapters of Arendt's book on totalitarianism. But in the eighth and ninth chapters dedicated to "Continental Imperialism" and the "Decline of the Nation-state and the End of the Rights of Man" respectively, she surprises the reader with a second thesis that connects the origin of totalitarianism to the nation-state itself. Her critique of modern society now reaches into its democratic state-constitution. In the sixth chapter she still denounced Burke's critique of the rights of man as the common source of "German and English race-thinking" (Arendt, 1979: 175; Arendt, 1991: 292). Then, in the ninth chapter, she adopts without question his critique of the French Revolution. Human rights are not only worthless to a people without a state to whom they should actually apply, but these rights of the "naked savages" (Arendt, 1979: 300) (Burke) carry the seeds of a new barbarism of Europe within them. Instead of elevating the "naked savages" into civic legal persons, the doctrine of human rights lowers the natural rights of this civic person to the status of the "naked savages". Just like the human rights of the subject are reduced to a world-less status, so the people, in the legal-constitutional concept of the nation and of popular sovereignty, are reduced to a socially retrograde and manipulable mob; the solitary masses.

In the end, Arendt explains the imperialistic outbreak of violence by appealing to the "horror" and "shock" that

"overcame Europeans when they got to meet the Negroes (Neger), not as individuals, exported exemplars, but as the population of an entire continent [...]. The horror before the fact that even people like these were human beings, and the immediately following decision that such 'human beings' could under no circumstances be their equal. [...] What distinguished them from other peoples was not the color of their skin; what also made them physically frightening and repulsive was their catastrophic [...] belonging to nature, against which they could not hold up a man-made world. Their unreality and ghostly wandering is due to this lack of worldliness [...]. Their unreality lies in the fact that they are human beings and, nevertheless, completely lack a specifically human reality. It is this given unreality of the aboriginal tribes together with their lack of worldliness that seduced Europeans into murderous destruction and utter lawlessness they displayed in Africa" (Arendt, 1991: 322, trans. Lemm). ${ }^{1}$ 
Contemporary readers will find it offensive that Arendt depicts African peoples living in tribal societies as unhistorical raw nature and, simultaneously, as the original figure of the mob in order to keep them apart from the historically educated, west European bourgeoisie. But this gesture typified the European bourgeoisie's way of thinking well into the 1960s. It is thus not without good reason that Adorno, who himself thought this way, drew this bourgeoisie together with Fascism when he wrote that the bourgeois was a virtual Nazi. Only since the mid-1960s, with the eruption of cultural revolutions such as that of the American "Rights Revolution" and with the increase in global protest and minority movements, was this self-understanding of white Europeans and Americans, oriented by the Eurocentric opposition between civilization and barbarism, shattered and rendered insecure.

But Arendt's point is not that the sight of blacks led to European imperialism: the latter, as we saw, is explained sociologically, as the consequence of the structural dynamics of modern European society. But the sight of "negroes," who appear "physically frightening and repulsive" due to "their belonging to nature, against which they could not hold up a man-made world," in short, the sight of inhuman humans, according to Arendt, did away with the last civilized inhibitions of Europeans, who already had to bear with these inhuman humans as an exported "surplus population" and as slaves, "seducing" them into "murderous destruction and utter lawlessness".

This is the context in which Arendt changes her mind, at the end of her book on totalitarianism, regarding Burke, the nation and the previously celebrated Jacobin human rights patriotism. Without realizing the self-contradiction, she revises her position and denounces human rights as the anticivic and counter-civilizational (and therefore ineffective) "rights of naked savages". The nation, which rests its nature-given sovereignty and "national self-determination" (Arendt, 1991: 434) on the basis of such human rights, now represents for her the irruption of raw nature into the civilized reign of a politics centered on the state (staatlich verfasster Politik). Popular sovereignty becomes the "sovereignty of naked savages," and the state that resists this transformation turns out to be the dusty old liberal constitutional state of $19^{\text {th }}$ century German jurisprudence. It is this state which finally had to collide against the "secret conflict between state and nation," breaking to pieces (Arendt, 1979: 230).

From this perspective, whenever the constitutional state unites with the nation in a democratic republic, the social enemy that wants its ruin has already been let into the house. The birth defect, the "tragedy of the nation-state," (Arendt, 1979: 230; Arendt, 1991: 370) is the democratic separation of powers. Once universal suffrage has been introduced, allowing the masses to enter politics, the once primary parliamentary legislature must now face, in the short or long run, the "conquest" and "instrumentalization" of the state at the hands of the nation (Arendt, 1979: 230; Arendt, 1991: 372). For Arendt, the nation is now the enemy of the state within the liberal state. Later, in On Revolution, she will remark almost casually that "the birth of the nation-state is the downfall of the free republic" (Arendt, 1974: 317, trans. Lemm).

(3) Against the background experience of National Socialist and Stalinist terror, Arendt draws the conclusion that on the basis of the nation and human rights, one cannot make a state. This means that no truly public life, no republic, can be built on those foundations. And yet, the bare constitutional state is much too abstract an entity for it had already demonstrated its fatal weakness to serve as such a foundation during its inglorious downfall under the Nazi Reich. During the $20^{\text {th }}$ century, where was one to find a way out of the totalitarian dilemma, a way that 
leads to the "light of humanity" (Arendt, 1991: 362, trans. Lemm)? At the end of The Origins of Totalitarianism, Arendt retains only two formulas that could replace the failed attempt by the Jacobin nation-state to give a new form to the old idea of the republic by means of the unity of popular sovereignty and human rights. The first formula is that of "the right to have rights" (Arendt, 1991: 462), which replaces the idea of human rights. Thereby Arendt clearly reduces human rights to the right to membership in a particular civilized community, whether the latter is democratically or autocratically constituted. The second formula is that of "natality," the Augustinian-Christian hope that at "every end in history," in this case the end of World War II, "a beginning can be made" (Arendt, 1979: 479; Arendt, 1991: 730). How these two formulas relate to each other and how they can be understood as an alternative to the nation-state is shown by Arendt's renewal of the classical positive-freedom conception of power and her return to the revolutionary origin of modern republicanism in the $18^{\text {th }}$ century.

The concept of power found in The Human Condition and On Revolution is a surprising reinterpretation and extension of the concept of power found in The Origins of Totalitarianism. Reflexively constituted and therefore unlimited power -"power that with each of its movements produces more power"- no longer appears as exclusively destructive. Power is no longer just the totalitarian self-increasing power. Through the reinterpretation of a notion of power, which originally was counterfeited for imperialism and totalitarianism, Arendt succeeds in drawing out of the modern conception of reflexive power a productive, simultaneously modern and classical, republican feature that can compete with the complexity of an imperial notion of power. This surprising synthesis of a modern concept of highly mobile, infinitely increasable and completely reflexive power with a classical understanding of politics as the public affair (res publica) is an impressive innovation in political theory. It shows that Arendt's sense for avant-garde modernism is as intense as her love for the ancient cradle of our political culture.

The general features of reflexive power, namely, that power can only become more powerful through power and that the "separation of powers makes a community more powerful than the centralization of power" (Arendt, 1974: 198), also apply to the power created by citizens in their public assemblies and common action. Power can only be increased through reflexive differentiation and decentralization. Arendt shares this thesis with Luhmann, for whom it is clear that "absolute power" in a complex society means "small power" (Luhmann, 1988: 30). Although power can be destroyed through violence, it cannot be "realized" through violence (Arendt, 1981: 193; Arendt, 1974: 196). Violence can be monopolized, but power cannot. Power is not at the disposal of those who are in power. It is a public thing and not a private property: "power springs up between men when they act together and vanishes the moment they disperse" (Arendt, 1958: 200; Arendt, 1981: 194).

By means of a federation that unites "separate and independently constituted bodies," common power is literally "predetermined" to "constant enlargement" (Arendt, 1979: 168; Arendt, 1974: 218). Public networked power is -and here Arendt's argument is amazingly similar to that of the otherwise despised American pragmatists- "destined to grow" and, since it is generated spontaneously and unpredictably out of common action, it favors the "desire for experimentation" (Arendt, 1974: 222). The power of the many knows no membership. This is why it is "from the start open to all," that is, for those who are willing to mutually commit themselves to a new beginning. Spontaneity, non-disposability and de-centered networking, transform the powerless public assembly, the bare talking and consulting with each other, into an "unlimited power" (Arendt, 1979: 
178; Arendt, 1974: 228). Not unlike the imperialistic power of "conquest" (Arendt, 1974: 218), this power is almost infinitely augmentable.

The experience of all revolutions is that a "popular revolt against materially strong rulers... may engender an almost irresistible power even if it foregoes the use of violence in the face of materially vastly superior forces" (Arendt, 1958: 200-1; Arendt, 1981: 194). For this reason, the imperial and dominating power that is violently established and predisposed to the use of violence can preserve itself within the political sphere of public affairs only as long as it is backed up by the "living power of the people": "All political institutions are manifestations and materializations of power; they petrify and decay as soon as the living power of the people ceases to uphold them" (Arendt, 1972: 140; Arendt, 1970: 42).

The concept of the living power of the people in the previous passage from On Violence is a literal reference to the American "people". This is why it should under no circumstances be mistaken with a concept of "people" understood as a homogeneous collective subject. This living power is the power (the capacity, potentia = potential) of action, that is, of acting in common, of "acting in concert" (Burke). For an adequate understanding of Arendt's text it is important to understand that this capacity is in no way good as such. Rather, like in the case of Jesus, who Arendt likes to cite in this context, it is a deeply ambivalent capacity. Acting is the power that has brought forth the Roman republic, the republican nation state, the Catholic church, the rule of the Committee for Public Safety, Napoleon's dictatorship, the Bolshevik dictatorship of the proletariat, and the Islamic republic.

Arendt adopts Jesus' saying, "For they know not what they do," as the (paradoxical) condition of possibility of political (and aesthetically-innovative) action (Arendt, 1994: 74). Action is a miracle which gives rise to novelty (Arendt, 1994: 192, 221) which can, in turn, lead towards the "light of humanity," but may also lead to terrible failure or horror without end. One cannot know beforehand, "for they know not what they do". The "men of the Revolution" always stare into an "abyss" (Arendt, 1979a: 30, 185). After all, one "cannot rely" on power and action is "the most dangerous of all human capacities and possibilities" (Arendt, 1994: 363).

Republican power distinguishes itself from imperialistic power through the feature of action. As acting in common, this republican power is powerless over the will of others (Arendt, 1981: 194). Power as potentia is positive freedom (Arendt, 1974: 194). Those who have power can do whatever they want. Common power is thereby not opposed to the power of the single individual. Just as in Spinoza's, Hegel's and Dewey's theories of power, the power of the individual grows along with the power of the community but without surrendering itself to the community (Brunkhorst, 2000: 225). Just as in Dewey's ideal democracy, Arendt's ideal republic optimizes the chances and possibilities, that is, the power of the individual to realize itself in and through the increasing power of the community. In Dewey's ideal democracy and in Arendt's ideal republic, the power that minorities and marginal voices have to be heard and recognized is greater than in any other regime. In taking an oppositional stance, in recognizing the frustration of expectations, and in abnormal and transgressing behavior, there lies not only "the capacity to correct mistakes" (Arendt, 1981: 236) but also the egalitarian origin of republican power. Everyone who says "no" or whose expectations have been frustrated (Arendt, 1979a: 67, 81, 86, 130) has this power. And the right to realize it is what Arendt calls "the right to have rights," in contrast to the abstract conception of human rights. Because the former right is determined from the start by the capacity 
of innovative negation, which Arendt considers the basic political capacity, namely, the capacity to act politically; it is thus a right to have rights. Accordingly, such a right, understood as a right to partake in a common political world, is from the start not an abstract but a concrete political right: the right of human beings to belong to a civic association.

Because individual action is always realized before others and always brings a new perspective into the light of the public sphere, Arendt's concept of action corresponds to what evolutionary theory calls the negation- and variation-potential of all activity. In contrast, the power of the community consists of a process of selection that transforms the new into "conventional" action, into an "opinion upon which many have agreed in public" (Arendt, 1970: 45; Arendt, 1974: 96). The question that Arendt addresses in On Revolution is how this power of acting in common, which only exists in its own realization and which, as we saw, cannot be relied upon, may nonetheless be stabilized into a permanent community without thereby fixating the "fleeting instant of acting in common" (Arendt, 1981: 195) into a rigid order. The question is not how power can be limited but how "to found a new one" (Arendt, 1965: 148; Arendt, 1974: 193).

Arendt tries to conjure an answer to this question by considering an impressive but also irritating array of possibilities, first by working her way through the example of the United States Constitution, and then by considering the utopia of the system of worker's councils (Rätesystem). Although it is now oriented towards Robespierre instead of Jefferson, Arendt's late republicanism, found in On Revolution, remains a modern republicanism not unlike her earlier Jacobin republicanism. Rather, it is her modernism that has shifted its ground, moving from a belief in the autonomy of human rights to a belief in the innovative-creative potential of continuity-disrupting action. Arendt is no longer concerned with the late Roman question of how Rome can be refounded in the hour of its downfall, but instead with the question that follows from the modern concept of revolution, namely, how can the power to found a "new Rome," which had never existed before, be established and constitutionally stabilized (Arendt, 1974: 273; Arendt, 1979a: 185, 195, 197). In the terms of systems-theoretical jargon, Arendt's question would be: How can variation generate stability?

I think that is an interesting question that touches the nerve of modern society and its political self-organization. But the innovative, world-building potential of common action remains, even in the later Arendt, essentially utopian. That is not an objection, but it betrays a weakness in her political thinking with regard to institutions. On Revolution describes the revolutionary founding of a modern constitutional regime out of a type of political constitution that is constituent of power. This type of constitution distinguishes the French and the American Revolution (contrary to Arendt's own restriction of this type of constitution to the American one) from the type of constitution that delimits power, developed in England and in Prussia, as a result of the reform of absolutist state power. However, because Arendt excludes from the start the possibility of founding a Constitution that is constituent of power on the autonomy of human rights (although such autonomy characterizes the constitutional history of both the United States and France), she necessarily misses the ordinary revolutionary power that has migrated from the revolutionary constitution to the body of statutes and ordinances that define the state administered law of modern democracies.

In the end, Arendt's arguments against the foundational role played by the autonomy of rights are motivated by the affect of the cultivated bourgeois against democracy. This is why her interpretation of the United States Constitution obscures the strictly egalitarian pattern of its division of powers, 
and instead highlights the role played by those organs of republican power-sometimes the Supreme Court, others the Senate or the Town Hall meetings of the past- which are characterized by the relatively low "number" of citizens participating in them and whose property is relatively equally distributed among the few. Rather than interpreting the division of powers of the United States Constitution in terms of the different steps through which a process of democratic will-formation acquires concretion, she interprets these divided powers as institutions containing a clever elite of politically (and not only technocratic) thinking heads designed to tame and bind the will of the people. This is the reason for Arendt's insistence on separating, as strictly as possible, the "seat of power" that lies in the people from the "source of law" that lies in the Constitution (see also, Arendt, 1974: 204, 229 f., 290 ff., 346 ff.). As a consequence, Arendt reduces the entire legal apparatus of a parliamentary democracy to the "non-revolutionary" function of "delimitation," which, in turn, is supposedly "independent from the form of the state" (Arendt, 1974: 186). What reappears here once again is nothing but the presumably neutral, government-invariant constitutional state imagined by the ideology of German public right which defines, in purely instrumental terms, the social function of law and of the constitution as the protection of the citizens against the state and against the people (Brunkhorst, 2003).

Arendt fails to see what contemporary democratic theory values about the type of constitution that is constituent of power. What made modern democracy possible was the constitutional innovation of both revolutions of the $18^{\text {th }}$ century, according to which, popular sovereignty is related to individual rights through a legal system characterized by a thoroughly democratically determined division of powers (Habermas, 1992). The entire point of the division and coordination of political and legal powers in a democratic Constitution is the guarantee for a free and equal will-formation of those who are subject to the normatively binding consequences of such a will. In this view, the doctrine of the division of powers, as expressed in the words of Herrmann Heller, "is nothing other than a technique [...] that allows the law-making volonté générale found in the law to rule" (Heller, 1928: $39 \mathrm{f}$., trans. Lemm). The organizational norms of the Constitution, the "entire system of checks and balances, such as elections, countersigning, parliamentarism, referendum, and popular initiatives," the juridification of the rights and duties of the president, the government, the legislative, etc. exist only for the sake of "legally guaranteeing that governmental power springs from the people" (Heller, 1971: 98, trans. Lemm).

The problem of institutionalizing the spirit of revolution in a pluralistic and individualistic constitution of free citizenship has a solution that is compatible with the principles of democracy only when a world-building and world-renewing concept of power is united with the autonomy of human rights proclaimed by the revolutions of the $18^{\text {th }}$ century. Such a unity depends on giving an interpretation of the concept of a people that lies at the basis of the principles of democracy and is inclusive and open to human rights. According to the interpretation offered by Friedrich Müller, the concept of a people, from which all state power flows and which is the only legitimate source of positive law, refers to the "whole which is subject to norms". The people therefore must be understood as an "open concept" whose "delimitation" must remain "the task of the political process" (Müller, 1997: 24, trans. Lemm).

From this perspective, one function of Arendt's innovative and spontaneous power would be to call into question the actual "delimitation" of the concept of the people, recognizing those who have been excluded from the status activus. Constituent power would consist in a thematization of such 
exclusions by articulating it and protesting against it in the process of public will-formation. The political process that concretizes the principles of the Constitution must allow for exactly that thematization of exclusion without thereby harming the equality of citizens. If social movements, such as those which triggered the great reforms of universal suffrage, the freedom of association and opinion, the worker's movement and the women's movement, are to transform themselves into public power, they stand in need of the innovative force of world-disclosing sentences such as, for example, those found in the Communist Manifesto. But without the principle of equal human rights one would lose the possibility to fight for the right to new freedoms: "The same equality of the Declaration of Independence," writes John Rawls, "which Lincoln invoked to condemn slavery can be invoked to condemn the inequality and oppression of women" (Rawls, 1993: xxxi). This, it seems, is what Jefferson meant when he gave an answer to the question of whether a Constitution can be rendered permanent. "I think not" for "nothing is unchangeable but the inherent and unalienable rights of man" (Arendt, 1979: 233; as cited by Arendt, 1974: 299). Political praxis is nothing but the unfolding of this paradox. Political praxis resolves this paradox by getting caught up in it, over and over again, and therein consists the productivity of power.

\section{ABBREVIATIONS}

OT The Origins of Totalitarianism

EU Elemente und Ursprünge totaler Herrschaft

HC The Human Condition

OR On Revolution

ov On Violence

\section{REFERENCES}

Arendt, Hannah. 1958. The Human Condition. Chicago: The University of Chicago Press.

Arendt, Hannah. 1965. On Revolution. London: Penguin Books.

Arendt, Hannah. 1970. Macht und Gewalt. München: Piper.

Arendt, Hannah. 1972. On Violence. In Crisis of the Republic, edited by. San Diego, New York, London: Harcourt Brace and Company, pp.

Arendt, Hannah. 1974. Über die Revolution. München: Piper.

Arendt, Hannah. 1976. Die verborgene Tradition. Frankfurt a. M.: Suhrkamp.

Arendt, Hannah. 1979. The Origins of Totalitarianism. San Diego, New York, London: Harcourt Brace and Company.

Arendt, Hannah. 1979a. Vom Leben des Geistes, Bd. 2: Das Wollen. München: Piper.

Arendt, Hannah. 1981. Vita activa oder vom tätigen Leben. München: Piper.

Arendt, Hannah. 1981a. Rahel Varnhagen. Lebensgeschichte einer deutschen Jüdin aus der Romantik. München: Piper.

Arendt, Hannah. 1991. Elemente und Ursprünge totaler Herrschaft. München: Piper.

Arendt, Hannah. 1994. Zwischen Vergangenheit und Zukunft. Übungen im politischen Denken 1. München: Piper.

Brunkhorst, Hauke. 2000. Einführung in die Geschichte politischer Ideen. München: Piper.

Brunkhorst, Hauke. 2003. "Der lange Schatten des Staatswillenspositivismus". Leviathan 3: 362-381.

Neumann, Franz. 1993. Behemoth. Struktur und Praxis des Nationalsozialismus 1933-1944. Frankfurt a. M.: Suhrkamp.

Fraenkel, Ernst. 1999. Gesammelte Schriften, Bd. 2: Nationalsozialismus und Widerstand. Baden-Baden: Nomos.

Fraenkel, Ernst. 2001. Doppelstaat. Hamburg: Europaische Verlagsanstalt.

Habermas, Jürgen. 1992. Faktizität und Geltung. Beiträge zur Diskurstheorie des Rechts und des demokratischen Rechtsstaats. Frankfurt a. M.: Suhrkamp. 
Heller, Hermann. 1971. Souveränität (1928) in Gesammelte Schriften, Bd. 2: Recht, Staat, Macht. Leiden: Mohr Siebeck. Luhmann, Niklas. 1988. Macht. Stuttgart: UTB.

Müller, Friedrich. 1997. Wer ist das Volk? Die Grundfrage der Demokratie - Elemente einer Verfassungstheorie VI. Berlin: Duncker \& Humblot.

Rawls, John. 1993. Political Liberalism. New York: Columbia University Press.

Hauke Brunkhorst es profesor titular ordinario y director del Instituto de Sociología de la Universidad de Flensburg desde 1997. Anteriormente enseñó filosofía y teoría política en la Universidad de Frankfurt y en la Universidad Libre de Berlín. Es autor de varios libros, entre ellos: Solidarity. From Civic Friendship to a Global Legal Community (2005, Cambridge/London: MIT Press); Einführung in die Geschichte politischer Ideen (2000, München: UTB); Hannah Arendt (1999, München: Beck, pronto en español); Adorno and Critical Theory (1999, Cardiff: University of Wales Press); y Solidarität unter Fremden (1997, Frankfurt: Fischer).

(E-mail:brunkhorst@uni-flensburg.de) 